\title{
PERAN PEMBERDAYAAN KESEJAHTERAAN KELUARGA DALAM PEMBERDAYAAN WANITA DI DESA SIMATAHARI KECAMATAN KOTA PINANG KABUPATEN LABUHANBATU SELATAN
}

\author{
Jam'ah Harahap, Fahrul Rizal \\ Pengembangan Masyarakat Islam Fakultas Dakwah dan Komunikasi \\ Universitas Islam Negeri Sumatera Utara \\ jamahharahap@gmail.com
}

\begin{abstract}
Abstrak
Penelitian ini bertujuan untuk mengetahui bagaimana pemberdayaan kesejahteraan keluarga (PKK) dalam hal pemberdayaan life skill, bagaimana pemberdayaan kesejahteraan keluarga (PKK) dalam hal pembinaan rohani, dan bagaimana pemberdayaan kesejahteraan keluarga (PKK) dalam pemberdayaan kesehatan, serta mengetahui hasil dari pemberdayaan yang telah diterapkan kepada para anggota PKK. Penelitian ini termasuk jenis penelitian lapangan yaitu peneliti untuk memperoleh data lapangan (data primer) yang bersifat deskriptif kualitatif. Metode yang digunakan adalah wawancara, observasi dan dokumentasi. Peneliti ini dilakukan di Desa Simatahari Kecamatan Kota Pinang Kabupaten Labuhanbatu Selatan. Hasil penelitian yaitu (1) pemberdayaan kesejahteraan keluarga dalam hal pemberdayaan life skill dengan memberikan modal berupa peralatan keterampilan, dan mengadakan pelatihan kepada anggota pemberdayaan kesejahteraan keluarga. (2) pemberdayaan kesejahteraan keluarga dalam hal pembinaan rohani yaitu mengadakan pengajian rutin dan yasinan akbar. (3) pemberdayaan kesejahteraan keluarga dalam hal pemberdayaan kesehatan yaitu mengadakan posyandu setiap bulannya.).
\end{abstract}

Kata Kunci: kesejahteraan keluarga, pemberdayaan wanita, pemberdayaan

\section{PENDAHULUAN}

Gerakan Pemberdayaan Kesejahteraan Keluarga (PKK) merupakan gerakan Nasional dalam pembangunan masyarakat. Bahwasanya pembangunan merupakan urusan seluruh rakyat Indonesia, bukan hanya urusan pemerintah, bahkan siapa saja yang merasa mampu, baik itu laki-laki atau wanita semua wajib ikut serta di dalam 
proses pembangunan tersebut. ${ }^{1}$ Oleh karena itu, wanita mempunyai hak, kewajiban dan kesempatan yang sama dengan pria untuk ikut serta sepenuhnya dalam segala kegiatan pembangunan.

Dalam rangka mendorong partsipasi wanita dalam pembangunan maka perlu dikembangkan kegiatan wanita dalam meningkatkan kesejahteraan keluarga antaralain, melalui pemberdayaan. Memberdayakan masyarakat adalah upaya untuk meningkatkan harkat dan martabat lapisan masyarakat yang dalam kondisi sekarang tidak mampu untuk kemudian dapat melepaskan diri dari perangkatkan kemiskinan dan keterbelakangan.

Dalam proses pemberdayaan maka perlu dikembangkan kegiatan wanita dalam meningkatkan kesejahteraan keluarga, antaralain melalui organisasi Pemberdayaan Kesejahteraan Keluarga (PKK). ${ }^{2}$ Peran Pembedayaan Kesejahteraan Keluarga (PKK) dalam pemberdayaan wanita merupakan segala tindakan yang dilakukan oleh PKK dengan tujuan meningkatkan kemampuan dan potensi yang dimiliki perempuan, agar secara mandiri wanita mempunyai keterampilan dan keahlian dalam menghadapi masalah yang mereka hadapi secara mandiri melalui peningkatan kapasitas dan kualitas hidup.

Seperti yang dilakukukan oleh organisasi PKK Desa Simatahari Kecamatan Kotapinang Kabupaten Labuhanbatu Selatan, pemberdayaan yang diterapkan kepada wanita yaitu berbagai hal pemberdayaan dan salah satunya adalah pemberdayaan keterampilan. Dengan adanya pemberdayaan wanita melalui keterampilan ini, ibu rumah tangga yang awalnya hanya mengurus rumah tangga, dan menghabiskan waktu untuk meonton televisi dirumah, dan berbincang-bincang sesuatu yang tidak bermanfaat, sekarang mendapatkan ilmu yang bermanfaat, dan dapat mengaplikasikannya dalam kehidupan sehari-hari, lebih menguntungkan lagi memiliki penghasilan, dan meningkatkan ekonomi keluarga.

\footnotetext{
${ }^{1}$ Hardjito Notopuro, Peran Wanita dalam Masa Pembangunan Indonesia,(Jakarta : Balai Aksara,1984), Cetakan Ke 2, hlm. 26

${ }^{2}$ Hardjito Notopuro, Peranan Wanita Dalam Masa Pembangunan Indonesia, hlm. 28 
Dengan penghasilan yang tidak terlalu banyak, tapi setidaknya dapat membantu ekonomi keluarga. Uang tersebuat biasanya ada yang ditabung, ada juga yang dipakai untuk jajan anak-anaknya dan kebutuhan pribadi para ibu-ibu tanpa harus meminta dari suami.

Pendapatan yang tidak seimbang dengan pendapatan karyawan kantor tidak menjadikan ibu-ibu di Desa Simatahari Kecamatan Kotapinang Kabupaten Labuhanbatu Selatan merasa iri dan malas. Karena mereka sadar di Organisasi PKK juga agar dapat membuat mereka untuk lebih aktif, selain peranannya sebagai ibu rumah tangga. Melainkan mereka dapat membuat keterampilan tas dirumah. Dengan begitu mereka juga tetap mendapatkan penghasilan.

Berdasarkan latar belakang masalah diatas, dalam rangka pemberdayaan wanita, melalui pemberdayaan keterampilan tas menjadi cukup penting dilakukan agar terciptanya kesejahteraan keluarga. Tujuan dalam penelitian ini adalah, (1) Untuk mengetahui Pemberdayaan Kesejahteraan Keluarga (PKK) dalam Pemberdayaan Life Skill di Desa Simatahari Kecamatan Kotapinang Kabupaten Labuhanbatu Selatan, (2) Untuk mengetahui Pemberdayaan Kesejahteraan Keluarga (PKK) dalam Pembinaan Rohani di Desa Simatahari Kecamatan Kotapinang Kabupaten Labuhanbatu Selatan, (3) Untuk mengetahui Pemberdayaan Kesejahteraan Keluarga (PKK) dalam Pemberdayaan Kesehatan di Desa Simatahari Kecamatan Kotapinang Kabupaten Labuhanbatu Selatan, dan (4) Untuk mengetahui hasil Pemberdayaan yang telah di terapkan PKK di Desa Simatahari Kecamatan Kotapinang Kabupaten Labuhanbatu Selatan.

Peran (role) merupakan aspek dinamis dalam kedudukan terhadap sesuatu. Apabila seseorang melakukan hak dan kewajibannya sesuai dengan kedudukannya maka dia menjalankan suatu peran. ${ }^{3}$

Teori yang mendukung penelitian ini adalah role theory (Teori Peran) yang dikemukakan oleh Sayogo yang dikutip dalam buku Kontribusi Ibu Rumah Tangga

${ }^{3}$ Soerjono Soekanto, Sosiologi Sebagai Pengantar, (Jakarta : PT Raja Grafindo Persada, 2001), hlm. 267 
dalam Meningkatkan Kesejahtaraan Keluarga, Teori peran menekankan sifat individual sebagai pelaku sosial yang mempelajari perilaku sesuai dengan posisi yang ditempatinya di lingkungan masyarakat. Teori peran mencoba untuk menjelaskan nteraksi antar individu, dalam organisasi, berfokus pada peran yang mereka lakukan. ${ }^{4}$

Peran yang di maksud dalam penelitian ini adalah perilaku seseorang sesuai dengan status kedudukannya di masyarakat. Jadi dapat disimpulkan bahwa peran adalah suatu aspek yang dinamis berupa tindakan atau perilaku yang dilaksanakan oleh orang atau badan lembaga yang menempati suatu posisi dalam situasi sosial.

Dengan demikian kaitan teori dengan penelitian ini adalah sesuai dengan tujuan peneliti secara umum, dimana peneliti akan melihat sejauhmana peran dari PKK dalam pemberdayaan wanita, dan dalam menjalankan program-program yang diterapkan PKK terhadap masyarakat (wanita).

\section{Teori Pemberdayaan}

Menurut Mas'oed yang dikutip dari Aprillia Theresia istilah pemberdayaan berasal dari penerjemah bahasa inggris empowerment yang dapat bermakna pemberian daya atau penguatan (Strengthening) kepada masyarakat. ${ }^{5}$

Teori pemberdayaan mencoba menjelaskan tentang pemberian daya atau penguatan kepada masyarakat. Berdasarkan teori yang dikemukakan diatas, pemberdayaan yang dimaksud dalam penelitian penulis adalah pemberdayaan wanita. Sesuai dengan pengertian pemberdayaan yaitu usaha untuk membuat yang tidak atau belum berdaya menjadi berdaya, maka harapannya dengan dilakukan pemberdayaan dapat membantu perempuan dalam mensejahterakan keluarga melalui pemberdayaan di bidang keterampilan.

\footnotetext{
hlm.11-12

${ }^{4}$ Nyoman, Kontribusi Ibu Rumah Tangga dalam Meningkatkan Kesejahteraan Keluarga

${ }^{5}$ Aprillia Theresia, Pembangunan Berbasis Masyarakat, (Bandung : Alfabeta, 2015) hlm. 117 


\section{Kerangka Konsep}

\section{Pemberdayaan Kesejahteraan Keluarga (PKK)}

Pemberdayaan Kesejahteraan Keluarga adalah gerakan Nasional dalam pembangunan masyarakat yang tumbuh dari bawah, pengelolaannya dari oleh dan untuk masyarakat menuju terwujudnya keluarga yang beriman dan bertaqwa kepada Tuhan Yang Maha Esa, berakhlak mulia dan berbudi luhur, sehat sejahtera, lahir dan batin. $^{6}$

\section{Pemberdayaan Wanita}

Pemberdayaan adalah suatu upaya untuk membangun daya itu dengan mendorong, memotivasi dan membangkitkan kesadaran akan potensi yang dimilikinya serta berupaya untuk mengembangkannya. ${ }^{7}$

Pemberdayaan adalah serangkaian kegiatan untuk memperkuat kekuasaan dan keberdayaan kelompok yang lemah di dalam masyarakat, termasuk individuindividu yang mengalami masalah kemiskinan, dan mempunyai tujuan untuk mencapai tujuan sebuah perubahan sosial yaitu masyarakat yang berdaya, memiliki kekuasaan atau mempunyai pengetahuan dan kemampuan dalam memenuhi kebutuhan hidupnya baik yang bersifat fisik, ekonomi, maupun sosial, seperti: memiliki kepercayaan diri, mampu menyampaikan aspirasi, mempunyai mata pencaharian, berpartisipasi dalam kegiatan sosial dan mandiri dalam melaksanakan tugas-tugas kehidupannya. ${ }^{8}$

Hal ini sejalan dengan firman Allah yang menyuruh manusia untuk selalu berusaha dalam menghadapi masalah hidup sebagai masalah pengembangan dan pemberdayaan umat Islam khususnya, sebagaimana dalam Al-Qur'an Srah Ar-ra'd/ 13 : 11 Allah berfirman, yang artinya : Baginya manusia ada malikat-malaikat yang selalu menjaganya bergiliran, dari depan dan belakangnya, mereka menjaganya atas

\footnotetext{
${ }^{6}$ Tim Penggerak PKK Pusat, Pemberdayaan dan Kesejahteraan PKK, (Jakarta : Tim Penggerak Pusat, 2015), hlm. 9

${ }^{7}$ Ginandjar Kartasasmitha, Pembangunan Untuk Rakya : Memadukan Prtumbuhan dan Pemerataan,(Jakarta : Ar Ruzz Media, 2007), hlm. 42

${ }^{8}$ Edi Suharto, Membangun Masyarakat Memberdayakan rakyat, (Bandung : Refika Aditama, 2005), hlm. 57 
perintah Allah. Sesungguhnya Allah tidak mengubah keadaan sesuatu kaum sebelum mereka mengubah keadaan diri sendiri. Dan apabila Allah menghendaki keburukan terhadap sesuatu kaum, maka tak ada yang dapat menolaknya dan tidak ada pelindung bagi mereka selain dia.

Dari ayat di atas menegaskan bahwa Allah tidak akan mengubah nasib suatu kaum, selama mereka tidak merubah dirinya sendiri. Maksudnya Allah menyuruh atau mengajak kita agar kamu berusaha dalam menghadapi permasalahan yang ada, tidak lengah dan putus asa yang mana pada dasarnya Allah tidak akan memberikan cobaan atau musibah kepada hambanya diluar kemampuannya dan tidak merubah nasib hambanya selama hamba tersebut tidak mau berusaha dan bertindak dalam mengatasi permasalahan yang ada dialami.

Menurut Novian, Pemberdayaan perempuan adalah upaya perempuanperempuan untuk memperoleh akses dalam kontrol terhadap sumber daya, ekonomi, politik, sosial, budaya, agar perempuan dapat mengatur diri dan meningkatkan rasa percaya diri untuk mampu berperan berpartisipasi aktif dalam memecahkan masalah, sehingga mampu membangun kemampuan dan konsep diri.

Sejalan dengan itu tujuan pemberdayaan perempuan adalah : 1) Meningkatkan kedudukan dan peran perempuan di berbagai bidang kehidupan berkeluarga, bermasyarakat, berbagsa dan bernegara. 2) Meningkatkan kualitas peranan perempuan sebagai pengembil keputusan dalam mewujudkan kesetaraan dan keadiland gender. 3) Meningkatkan kualitas peran kemandirian organisasi perempuan dengan mempertahankan nilai persatuan dan kesatuan. 4) Meningkatkan komitmen dan kemampuan semua lembaga yang memperjuangkan kesetaraan dan kedailan gender. 5) Mengembangkan usaha pemberdayaan perempuan, kesejahteraan keluarga dan masyarakat serta perlindungan anak. ${ }^{9}$

\footnotetext{
${ }^{9}$ Gagan Ganjar \& Mukran Roni, Pemberdayaan Perempuan Melalui Daya Saing Produk Berbahan Ramah Lingkungan dan UKM, Jurnal Vol 1 No 2, 2015 hlm. 33 


\section{Skill (Keterampilan)}

Skill adalah kemampuan untuk menggunakan akal, fikiran, dan ide, dan kreatifitas dalam mengerjakan, mengubah ataupun membuat Sesuatu menjadi lebih bermakna sehingga menghasilkan sebuah nilai dari hasil pekerjaan tersebut.

\section{Pelaksanaan Pemberdayaan Perempuan Melalui Keterampilan}

\section{Perencanaan Pembinaan Keterampilan}

Perencanaan yang dilakukan dalam menentukan pembinaan keterampilan adalah dengan mengidentifikasi potensi, minat dan bakat yang dimiliki oleh perempuan.

\section{Pelaksanaan Pembinaan Keterampilan}

Pelaksanaan Kegiatan pembinaan keterampilan dengan memberikan materi terlebih dahulu sebelum masyarakat melakukan praktek langsung.

\section{Evaluasi Pembinaan Keterampilan}

Tahap evaluasi yang dilakukan biasanya ketika proses pembinaan keterampilan berjalan dengan mengamati secara langsung saat melakukan kegiatan keterampilan ataupun dengan melakukan taya jawab.

\section{METODE PENELITIAN}

Penelitian ini adalah penelitian kualitatif, yaitu sebuah penelitian yang menguraikan secara mendalam tentang apa yang diperoleh dari orang lain, baik berupa kata-kata tertulis atau lisan dari orang-orang dan perilaku yang dapat diamati. Penelitian ini dilakukan juga dengan berusaha memahami objek penelitian sesuai dengan fakta yang ada dilapangan tanpa bermaksud memanipulasi.

Penelitian ini dilakukan di Desa Simatahari Kecamatan Kotapinang Kabupaten Labuhanbatu Selatan. Fokus penelitian ini berada di Aula Balai Pertemuan Kantor Desa dengan kegiatan keterampilan, dan di los pekan dengan kegiatan kesehatan, sedangkan kegiatan pengajian berada di Masjid Baiturrahman Simatahari. 
Sumber data dalam penelitian ini terdiri dari data primer yaitu data yang diperoleh langsung dari objek yang diteliti (nara sumber). Data tersebut diperoleh melalui observasi, wawancara, dan dokumentasi.

Dalam penelitian ini yang menjadi data primer yaitu bersumber dari wawancara langsung dan wawancara mendalam (indent interview) dengan pihak pengurus PKK, dan) yang telah merasakan dari hasil program pemberdayaan yang diterapkan oleh Tim Penggerak Pemberdayaan Kesejahteraan Keluarga (PKK).

Sedangkan data sekunder yaitu data yang diperoleh dari dokumen-dokumen resmi, buku-buku yang berhubungan dengan objek penelitian dalam bentuk laporan, skripsi, disertai Peraturan Perundang-undangan, dan lain-lain. Sedangkan data sekunder dalam penelitian ini, diantaranya buku-buku yang terkait dengan judul penelitian, dokumentasi kegiatan PKK dalam pemberdayaan wanita.

Dalam penelitian ini yang menjadi informan adalah Pengurus TP PKK, dan masyarakat yang telah merasakan hasil program pemberdayaan yang diterapkan di Desa Simatahari Kecamatan Kotapinang Kabupaten Labuhanbatu Selatan.

Teknik yang digunakan dalam penelitian ini untuk menganalisis data yang diperoleh adalah teknik induktif dan deduktif. Adapun tahapan menganalisis data yang dilakukan oleh peneliti adalah sebagai berikut :

1. Pengumpulan data dilakukan dengan mengumpulkan data dari sumber data kunci yakni ketua PKK melalui wawancara kegiatan yang dilakukan dalam rangka peran PKK dalam pemberdayaan wanita.

2. Setelah itu, yaitu mereduksi data, data dari hasil wawancara peneliti dengan beberapa narasumber, serta hasil dokumentasi dalam bentuk catatan lapangan selanjutnya dianalisis oleh penulis.

3. Penyajian data adalah sekumpulan informasi yang telah tersusun yang memberi kemungkinan adanya penarikan kesimpulan dan pengambilan tindakan. Penyajian data dilakukan dengan menghubungkan informasi yang diperoleh dari hasil wawancara dengan beberapa sumber data dan dokumentasi. 
4. Tahap terakhir yaitu verifikasi dan penarikan kesimpulan, dimana peneliti melakukan interprestasi dan penetapan makna dari data yang tersaji. Kegiatan ini dilakukan dengan cara pengelompokan. Data yang tersaji kemudian dirumuskan menjadi kesimpulan sementara. Kesimpulan sementara tersebut senantiasa akan terus berkembanag sejalan dengan pengumpulan data baru dan pemahaman baru dari sumber data lainnya. Sehingga akan di peroleh suatu kesimpulan yang benar-benar sesuai dengan keadaan yang sebenarnanya.

\section{HASIL PENELITIAN DAN PEMBAHASAN}

Desa Simatahari merupakan salah satu Desa yang terletak di Kecamatan Kotapinang Kabupaten Labuhanbatu Selatan. Desa ini memiliki luas wilayah 4790 Ha, dan terdiri atas enam dusun yaitu, Dusun Bakti, Dusun Makmur, Dusun Perjuangan, Dusun Sentosa, Dusun Sejahtera, Dusun Padangri HTI, Dusun Aek Hije. Jumlah penduduk di Desa Simatahari dengan jumlah 3.838 Jiwa yang terdiri dari 929 KK (Kepala Keluarga) dengan rincian Laki-laki sejumlah 1.860 jiwa sedangkan jumlah perempuan sebanyak 1.978 jiwa. Keadaan penduduk berdasarkan jenis kelamin di Desa Simatahari.

\section{Pemberdayaan Kesejahteraan Keluarga dalam hal Pemberdayaan Life Skill}

1. Keterampilan Tas Tali Kur

Keterampilan merupakan salah satu program Pemberdayaan Kesejahteraan Keluarga (PKK). Keterampilan ini juga termasuk dalam Program Kerja II PKK Desa Simatahari. adapun pokja II yang diterapkan PKK Simatahari berupa Keterampilan tas dan dompet bahan tali kur.

Sebagaimana hasil wawancara dengan ibu Harianti selaku ketua PKK mengatakan agar proses kegiatan dalam pembuatan keterampilan tas tali kur berjalan dengan baik, maka sebelum memulai pelatihan keterampilan tas tali kur ketua PKK, yaitu 
a. Memberikan bimbingan

Bimbingan dan arahan yang dilaksanakan oleh Ketua Pemberdayaan Kesejahteraan Keluarga guna untuk terarahnya suatu kegiatan, dan sekaligus membagikan peralatan-peralatan keterampilan kepada anggota yang ikut dalam pelatihan keterampilan tas tali kur.

b. Memberikan Peralatan

Peralatan yang diberikan ketua Pemberdayaan Kesejahteraan Keluarga kepada anggota berupa gunting, tali kur, res, kain lapis, benang jahit dan benang jahit.

c. Mengadakan pelatihan

Dalam pelatihan ini yang menjadi instruktur adalah Ibu Rosita Hasibuan. Pelatihan ini dilaksanakan agar membantu memperbaiki ekonomi ibu-ibu atau yang tergabung dalam anggota PKK Desa Simatahari, dan menjadi lebih mandiri, serta dapat menolong ekonomi keluarga mereka.

d. Melakukan pemasaran

Tas tali kur dipasarkan Ke Kota Bloksongo Kecamatan Kotapinang Kabupaten Labuhanbatu Selatan. Harga 1 tas ukuran kecil Rp 150.000, sedangkan tas ukuran besar Rp 350.000. ${ }^{10}$

\section{Keterampilan Pembuatan Sabun Cair}

Keterampilan pembuatan sabun cair merupakan Pokja II Desa Simatahari. adapun bentuk pelaksanaan kegiatan keterampilan sabun cair yaitu : pertama, musyawarah dan arahan bimbingan dari ketua PKK. Kedua, pembagian tugas kegiatan pembuatan sabun cair dan ketiga, memberikan bahan-bahan keterampilan kepada anggota Pemberdayaan Kesejahteraan Keluarga.

Kegiatan keterampilan sabun cair ini tidak adanya melakukan pemasaran, melainkan keterampilan tersebut hanya untuk kebutuhan dirumah para anggota PKK. Kegiatan ini diaksanakan agar anggota Pemberdayaan Kesejahteraan Keluarga dapat

10 Evi Harianti, Ketua Pemberdayaan Kesejahteraan Keluarga, "Desa Simatahari", Wawancara Pribadi, 15 Maret 2019 
lebih mandiri, dan mengembangkan potensi para anggota Pemberdayaan Kesejahteraan Keluarga (PKK). Sehingga para wanita yang tadinya tidak bisa membuat keterampilan pembuatan sabun cair, namun sekarang sudah dapat menerapkannya dengan sendirinya. Dan yang tadinya membeli ke kedai tetapi dengan adanya kegiatan pelatihan, dapat memanfaatkan skill yang mereka punya, dengan begitu wanita menjadi lebih mandiri.

\section{Keterampilan Memasak}

Keterampilan memasak merupakan program kerja (pokja) II Pemberdayaan Kesejahteraan Keluarga (PKK) Simatahari. Keterampilan memasak terdiri dari beberapa kegiatan, anataralain: pembuatan kue bolu, pembuatan keripik, kue basah, dan lain-lain.

Proses pemberdayaan keterampilan memasak sama seperti kegiatan keterampilan lainnya antaralain: Bimbingan dan arahan dari ketua Pemberdayaan Kesejahteraan Keluarga (PKK), pembagian kerja dan mengadakan pelatihan.

Dalam melaksanakan keterampilan memasak yang menjadi instruktur yaitu Ibu Qori Anggreani yang berdomisili di Dusun Bakti Padangrie Simatahari. Ibu Qori Anggreani merupakan salah satu masyarakat pembuatan berbagai macam kue. Keterampilan memasak yang diterapkan berupa pembuatan kue bolu, kue basah, dan berbagai macam keripik dan lain-lain.

Kemudian kue-kue yang telah dibuat dipasarkan ke kotapinang, namun sekarang bentuk pemasaran kue untuk saat ini ketika adanya permintaan dari konsumen.

\section{Pemberdayaan Kesejahteraan Keluarga dalam hal Pembinaan Rohani}

Pemberdayaan Kesejahteraan Keluarga dalam hal pembinaan Rohani dilaksanakan karena adanya usulan dari Kabupaten Labuhanbatu Selatan. Pembinaan rohani ini juga memang harus dilaksanakan oleh organisasi Pemberdayaan Kesejahteraan Keluarga (PKK) Simatahari, agar adanya kegiatan pembinaan rohani untuk setiap bulannya. Adapun kegiatan yang dilaksanakan berupa yasinan akbar dan pengajian rutin. 
Pembinaan rohani diadakan setiap bulannya dan berada di Masjid Baiturrahman Desa Simatahari Kecamatan Kotapinang kabupaten Labuhanbatu Selatan, dengan kegiatan yang dilakukana yaitu yasinan akbar dan pengajian rutin.

\section{Pemberdayaan Kesejahteraan Keluarga dalam hal Pemberdayaan Kesehatan}

Kesehatan merupakan salah satu program Pemberdayaan Kesejahteraan Keluarga, kesehatan termasuk dalam poin ke tujuh dari sepuluh program pokok PKK yang diterapkan disetiap jenjang. Kesehatan ini juga termasuk dalam program kerja IV PKK Desa Simatahari. Adapun pokja IV yang diterapkan Pemberdayaan Kesejahteraan Keluarga (PKK) Simatahari berupa pemberdayaan kesehatan pada balita dan lansia.

Sebagaimana hasil wawancara dengan dengan Ibu Linda, mengatakan bahwa Posyandu Desa Simatahari bernama Posyandu Mawar, dimana kegiatan posyandu yang diterapkan Pemberdayaan Kesejahteraan Keluarga (PKK) dilaksanakan setiap bulannya, dan dilaksanakan di Los Pekan Desa Simatahari.

Pada balita, Posyandu Mawar Simatahari mengadakan penyuntikan untuk usia 0-12 bulan, dan Pemberian makanan tambahan (PMT). Makanan tambahan yang diberikan adalah susu, bubur kacang hijau, pisang. Makanan-makanan tersebut dipilih karena mengandung gizi yang baik dan disukai oleh balita. Dengan adanya program ini agar dapat memberikan pengenalan gizi kepada ibu-ibu terhadap anakanaknya, dan supaya masyarakat lebih peduli dengan gizi sehat.

Pada lansia Posyandu Mawar Simatahari mengadakan periksa kesehatan fisik para lansia dan di periksa kesehatannya oleh petugas kesehatan, baik keluhan pada saat di periksa, tekanan darah, pemeriksaan kimia darah (kolestrol, gula darah, asam urat), dan sebagainya. Posyandu lansia juga mengadakan olahraga ringan yang sesuai untuk usia mereka, yang diadakan setiap hari minggu. ${ }^{11}$

\footnotetext{
${ }^{11}$ Linda Sari, Ketua Pokja IV Pemberdayaan Kesejahteraan Keluarga, "Desa Simatahari" Wawancara Pribadi, 22 Maret 2019 


\section{Hasil Pemberdayaan}

Tujuan dari dilaksanakannya kegiatan Pemberdayaan Life skill adalah adanya perubahan yang terjadi dalam diri anggota Pemberdayaan Kesejahteraan Keluarga, salah satu perubahan yang diharapkan yakni perubahan sikap kemandirian dan motivasi dalam diri dan mengembangkan potensi yang dimiliki para wanita.

Adapun hasil pemberdayaan Life skill yaitu dapat meningkatkan ekonomi keluarga, yang mana anggota Pemberdayaan Kesejahteraan Keluarga telah sukses dalam hasil pemberdayaan Kesejahteraan Keluarga. Dengan keterampilan tas tali kur ini memiliki penghasilan yang cukup besar dalam proses penjualan. Adapun penghasilan yang diperoleh sebesar Rp 21.000.000/bulan, dan itu semua sudah termasuk penghasilan kotor dengan biaya modal untuk membeli alat dan bahan pembuatan tas maupun dompet.

Pembinaan Rohani yang dilaksanakan Pemberdayaan Kesejahteraan Keluarga dilaksanakan untuk setiap bulannya, seperti yasinan akbar, dan pengajian. Namun sekarang mulai tidak rutin setiap bulannya dikarenakan adanya faktor penghambat dari kegiatan lain masyarakat. Sehingga pembinaan rohani ini masih kurang aktif dalam proses menjalankan kegiatan pembinaan rohani.

Pemberdayaan Kesehatan dapat menjalankan pola hidup sehat, yang mana ibu-ibu dapat memberikan asupan gizi yang baik untuk anak-anak mereka. Dan terus mengikuti kegiatan rutin Posyandu Mawar Simatahari yang di adakan di Los Pekan Simatahari. Sementara para Lansia menjadi lebih semagat untuk menjalankan pola hidup sehat, dan para lansia setiap bulannya untuk ikut melakukan periksa tekanan darah, pemeriksaan kimia darah (kolestrol, gula darah, asam urat), dan sebagainya.

\section{KESIMPULAN}

Berdasarkan uraian terdahulu yang penulis teliti dan rangkum dalam sub bab tertentu, maka penulis mengambil beberapa kesimpulan yang terkait tentang Peran Pemberdayaan Kesejahteraan Keluarga Dalam Pemberdayaan Wanita Di Desa Simatahari Kecamatan Kotapinang Kabupaten Labuhanbatu Selatan. 
1. Pemberdayaan Kesejahteraan Keluarga dalam hal pemberdayaan Life Skill di Desa Simatahari Kecamatan Kotapinang Kabupaten Labuhanbatu Selatan, yaitu pertama, memberikan bimbingan. Kedua, memberikan peralatan, Ketiga, memberikan pelatihan dan keempat, melakukan pemasaran.

2. Pembinaan rohani dilaksanakan setiap bulannya, kegiatan yang dilaksanakan yaitu yasinan akbar, dan pengajian rutin. Namun sekarang kegiatan pembinaan rohani sudah mulai tidak aktif dikarenakan adanya kesibukan masyarakat dengan kegiatan mereka masing-masing. Jadi kegiatan yasinan yang awalnya dilakukan setiap bulannya, namun sekarang tidak setiap bulannya dilaksanakan.

3. Pemberdayaan kesehatan dilaksanakan secara rutin setiap bulannya. Pemberdayaan kesehatan pada balita yaitu mengadakan penyuntikan untuk usia 0-12 bulan, memberikan susu kepada bailta. Pemberian makanan tambahan (PMT) untuk balita. Sedangkan pada lansia yaitu mengadakan periksa kesehatan, baik keluhan saat diperiksa, tekanan darah, pemeriksaan kimia darah (kolestrol, gula darah, asam urat), dan sebagainya. Posyandu lansia biasanya rutin mengadakan olahraga ringan, yaitu senam sehat yang diadakan setiap hari minggu. Selain itu penyuluhan mengenai pola hidup sehat bagi lansia.

4. Hasil pemberdayaan

Hasil pemberdayaan dalam hal Life Skill organisasi Pemberdayaan Kesejahteraan Keluarga telah berhasil dalam menjalankan pemberdayaan Life skill. Seperti keterampilan tas tali kur, keterampilan pembuatan sabun cair, keterampilan memasak. Wanita menjadi lebih mandiri dan dapat meningkatkan pendapatan ekonomi keluaraga.

Sedangkan pembinaan Rohani, masih belum stabil dalam melaksanakan kegiatan keagamaan seperti yasinan akbar, dan pengajian, karena sebelumnya sudah pernah aktif untuk setiap bulannya, sementara sekarang adanya faktor penghambat dalam menjankan kegiatan pembinaan rohani, dikarenakan adanya kegiatan lain masyarakat. 
Pemberdayaan Kesehatan, terlaksananya pola hidup sehat bagi balita maupun lansia. Karena sebelumnya diadakan penyuluhan pola hidup sehat. Dan pemberian makanan tambahan bagi balita, dan untuk lansia memeriksa kesehatan seperti cek kadar gula, kolestrol, tensi, dan mengadakan senam sehat.

\section{SARAN}

1. Hendaknya pembemberdayaan Life skill tidak hanya berfokus pada anggota PKK, tetapi masyarakat di luar Organisasi PKK juga dapat diberdayakan dalam hal pemberdayaan life skill.

2. Bagi anggota PKK Desa Simatahari Kecamatan Kotapinang agar bisa lebih aktif lagi dalam menjalankan program-program PKK, terutama dalam hal pemberdayaan, agar menjadi lebih berdaya.

3. Kepada para peneliti yang tertarik dengan judul penelitian ini, diharapkan lebih dapat mengembangkan metodologi penelitian yang berkualitas untuk menghasilkan penemuan yang lebih alamiah.

\section{DAFTAR PUSTAKA}

Edi Suharto, 2005, Membangun Masyarakat Memberdayakan rakyat, Bandung : Refika Aditama

Ganjar Gagan dan Mukran Roni, 2015, Pemberdayaan Perempuan Melalui Daya Saing Produk Berbahan Ramah Lingkungan dan UKM, Jurnal Vol 1 No 2

Hardjito, 1984, Peran Wanita dalam Masa Pembangunan Indonesia,Jakarta : Balai Aksara

KartasasmithGinandjar a, 2007, Pembangunan Untuk Rakya : Memadukan Pertumbuhan dan Pemerataan, Jakarta : Ar Ruzz Media,

Nyoman, Kontribusi Ibu Rumah Tangga dalam Meningkatkan Kesejahteraan Keluarga 


\section{JURNAL PEMBERDAYAAN MASYARAKAT $\mid 127$ \\ Volume 7 No. 2 Tahun 2019 ISSN: 2355-8679}

Soekanto Soerjono, 2001, Sosiologi Sebagai Pengantar, Jakarta : PT Raja Grafindo Persada

Theresia Aprillia, 2015, Pembangunan Berbasis Masyarakat, Bandung : Alfabeta

Tim Penggerak PKK Pusat, 2015, Pemberdayaan dan Kesejahteraan PKK, Jakarta : Tim Penggerak Pusat 